\title{
Stigma dan diskriminasi serta strategi koping pada orang dengan HIV dan AIDS (ODHA) di kota Medan, Sumatera Utara
}

\author{
Eva Kartika Hasibuan ${ }^{1 *}$, Novita Aryani2, Galvani Volta Simanjuntak ${ }^{3}$ \\ 1,2,3Program Studi Ners, Universitas Sari Mutiara Indonesia. *Email: evakartikahsb86@gmail.com
}

\begin{abstract}
People living with HIVIAIDS (PLWHA), battling stigma, discrimination and coping strategies in Medan, Indonesia
\end{abstract}

Background: People living with HIVIAIDS have a multiple problem, PLWHA has a decreased physical abilities effect immunodeficiency, but also having a psychological and social problems also increase their burden. The health provider should be a place for PLWHA to get the right information about HIVIAIDS, but they follow to stigmatize and discriminate against them.

Purpose: To describe coping PLWHA face up to stigma and discrimination in health provider.

Methods: A qualitative with a descriptive phenomenological approach with population of this research was people living with HIVIAIDS (PLWHA) in Medan, Indonesia. The number of samples was of 10 respondent by purposive sampling technique. The criteria of the sample were PLWHA get treatment for $\geq 6$ months and able to communication in Indonesia is well. Data collected with in-depth interviews and analysis by Nvivo version 12.0 trial.

Result: Finding that four themes, the first; get stigmatize and discriminate from health workers, second; have a psychological impact, third; continue treatment to the health provider and fourth; Hoping in health services well.

Conclusion: People living with HIVIAIDS (PLWHA) in Medan Indonesia still having a positive coping to face stigma and discrimination in health provider and they keep continue to get treatment in health provider..

Keyword: People Living With HIVIAIDS (PLWHA); Battling; Stigma; Discrimination; Coping Strategies

Pendahuluan: Pelayanan kesehatan yang seharusnya menjadi tempat orang dengan HIVIAIDS mendapatkan pengobatan dan informasi yang benar mengenai penyakitnya, justru ikut menstigma dan mendiskriminasikan mereka.

Tujuan: Untuk menggambarkan stigma, koping dan harapan ODHA di pelayanan kesehatan.

Metode: Penelitian kualitatif dengan pendekatan fenomenologi deskriptif dengan populasinya orang dengan HIVIAIDS (ODHA) di Kota Medan. Jumlah partisipan sebanyak 10 orang yang diambil dengan teknik purposive sampling. Pengumpulan data dengan wawancara mendalam dan data dianalisis dengan menggunakan software N.Vivo versi 12 trial.

Hasil: Di dapatkan empat tema yaitu 1) Pernah mendapatkan stigma dan diskriminasi dari petugas kesehatan, 2) Pernah mengalalami dampak secara psikologis, 3) Tetap melanjutkan pengobatan ke pelayanan kesehatan, 4) Harapan pada layanan kesehatan.

Simpulan: Orang dengan HIVIAIDS ODHA di kota Medan masih memiliki koping yang positif dalam menghadapi stigma dan diskriminasi sehingga ODHA tetap melanjutkan pengobatan di pelayanan kesehatan.

Kata Kunci : Stigma; Diskriminasi; Strategi Koping; Orang Dengan HIV dan AIDS (ODHA) 


\section{PENDAHULUAN}

Human Immunodeficiency virus (HIV) dan Acquired Immune Deficiency Syndrome (AIDS) masih menjadi masalah kesehatan global sampai saat ini. Meskipun laju kejadian HIV telah menurun dari 0,40 per 1000 menjadi 0,26 per 1000 orang yang tidak terinfeksi di tahun 2016 ( The Joint United Nations Programme on HIV and AIDS (UNAIDS), 2018), namun kecenderungannya masih memprihatinkan. Hingga akhir tahun 2017, World Health Organization (WHO) melaporkan terdapat sekitar 36,9 juta orang dengan HIVIAIDS (ODHA), 940.000 kematian karena HIV, dan 1,8 juta orang terinfeksi baru HIV atau sekitar 5000 infeksi baru per harinya (Utami, 2018).

Permasalahan yang dialami ODHA sangat kompleks. ODHA tidak hanya mengalami penderitaan fisik karena proses penyakit, melainkan juga penderitaan pada fungsi psikososial (Carsita, Winarni, \& Lestari, 2016). Orang Dengan HIVIAIDS (ODHA) mengalami stigma dan diskriminasi oleh keluarga, teman dan masyarakat (Indriani, \& Fauziah, 2017).

Stigma dan diskriminasi dapat terjadi dimana saja baik di lingkungan sekitar tempat tinggal ODHA, tempat kerja, sekolah, tempat ibadah, maupun di pusat-pusat pelayanan kesehatan. Pelayanan kesehatan sebagai lembaga yang diharapkan memberikan perawatan dan dukungan pada ODHA, pada kenyataannya merupakan tempat pertama ODHA mengalami stigma dan diskriminasi (Kharimaturrohmah \& Shaluhiyah, 2013).

Stigma dari petugas kesehatan membuat pasien ODHA merasa tidak nyaman berada di pelayanan kesehatan (Waluyo, Nova, \& Edison, 2011). Hal ini terkait dengan mekanisme koping mereka. Apabila koping mereka negatif dapat berdampak pada meningkatnya isolasi sosial dan depresi atau hambatan untuk akses pelayanan kesehatan bagi ODHA yang secara langsung maupun tidak langsung dapat berakibat pada penurunan cakupan terapi HIV dan AIDS yang pada akhirnya dapat berakibat peningkatan angka ODHA dan juga menurunkan kualitas layanan kesehatan kepada pasien ODHA dan program pencegahan penularan HIV dan AIDS (Kharimaturrohmah \& Shaluhiyah, 2013). Melihat permasalahan diatas bahwa stigma dan diskriminasi ODHA juga dilakukan oleh petugas kesehatan, peneliti tertarik untuk mendapatkan informasi mendalam mengenai koping ODHA menghadapi stigma dan diskriminasi di pelayanan kesehatan.

\section{METODE PENELITIAN}

Penelitian menggunakan pendekatan fenomenologi deskriptif. Subjek penelitian ini adalah orang yang didiagnosa HIVIAIDS yang mendapat dampingan dari Medan Plus dan melakukan pengobatan di Kota Medan. Pengambilan sampel secara purposive sampling dengan kriteria telah menjalani pengobatan $\geq 6$ bulan dan mampu berkomunikasi dengan baik dalam bahasa Indonesia, didapatkan 10 orang partisipan dan data telah mencapai saturasi.Pengumpulan data dilakukan dengan metode wawancara mendalam (indepth interview) yang dilakukan oleh peneliti sendiri dengan durasi 40-60 menit. Wawancara dilakukan dengan menggunakan panduan wawancara yang berisi butir-butir pertanyaan untuk diajukan kepada partisipan. Untuk meyakinkan partisipan bahwa dalam penelitian ini partisipan dilindungi, peneliti memperhatikan aspek kebebasan, menghormati hak-hak partisipan, prinsip anonimity, confidentiality, dan protection from discomfort. Selain itu, sebelum melakukan pengumpulan data, peneliti terlebih dahulu melakukan uji etik di komite etik penelitian Universitas Muhammadiyah Sumatera Utara dan dinyatakan lolos uji etik dengan nomor surat 254/KEPK/FKUMSU/2019. Data-data yang telah dikumpulkan akan dianalisis untuk menemukan kata kunci, subtema dan tema. Analisis data menggunakan software Nvivo 12.0 versi trial.

\section{HASIL}

Usia partisipan berusia 21-32 tahun, dengan jenis kelamin laki-laki sebanyak 8 partisipan dan perempuan sebanyak 2 partisipan dan tingkat pendidikan sarjana sebanyak 7 partisipan dan SMA sebanyak 3 partisipan. Hasil penelitian menemukan tiga tema utama yang menjelaskan koping ODHA menghadapi stigma dan diskiminasi di pelayanan kesehatan, diantaranya:

\section{Mendapatkan stigma dan diskriminasi dari petugas kesehatan}

Hasil penelitian menemukan bahwa stigma dan diskriminasi yang diterima ODHA adalah

Eva Kartika Hasibuan ${ }^{{ }^{*}}$, Novita Aryani ${ }^{2}$, Galvani Volta Simanjuntak ${ }^{3}$

Program Studi Ners, Universitas Sari Mutiara Indonesia. *Email: evakartikahsb86@gmail.com 
mendapatkan pelecehan secara verbal oleh petugas kesehatan. Mereka merasa dilecehkan, dikira sampah dan dijelek-jelekkan oleh petugas kesehatan. ODHA juga menerima perlakukan negatif dari petugas kesehatan. Perlakuan negative yang diterima ODHA seperti petugas kesehatan tidak care terhadap mereka, apabila ada complain mereka marah, layanan yang lambat, jutek dan cuek.

\section{Mengalami dampak secara psikologis}

Stigma dan diskriminasi yang dialami ODHA berdampak pada psikologisnya. Hal ini membuat perubahan mental pada ODHA. hasil penelitian mendapatkan bahwa stigma menimbulkan rasa takut pada ODHA, gampang sensitive dan juga membuat pasien merasa"down".

\section{Melanjutkan Pengobatan ke Layanan Kesehatan}

Meskipun menerima stigma dan diskriminasi dari petugas kesehatan, ODHA tetap melanjutkan pengobatan ke layanan kesehatan. Di awal, stigma dan diskriminasi petugas kesehatan menyebabkan ODHA tidak mau atau terlambat mengakses layanan terkait HIV, seiring dengan penerimaan diri dan penyesuaian yang dilakukan, mereka kembali melanjutkan pengobatan. Cepat lambatnya penerimaan dan penyesuaian diri ODHA terkait dengan koping diri ODHA. hasil penelitian menemukan bahwa koping yang dilakukan ODHA terhadap stigma dan diskriminasi dari petugas kesehatan adalah tidak mengambil hati, pindah layanan kesehatan, dan menerima.

\section{Harapan terhadap layanan kesehatan}

Koping yang positif, membuat ODHA memiliki harapan terhadap penyakitnya. Hasil penelitian mendapatkan bahwa ODHA berharapan bisa sembuh, obat HIV ditemukan, dan obat tetap gratis. Selain itu, layanan kesehatan terhadap mereka ditingkatkan seperti melakukan penyuluhan secara berkala, melakukan kunjungan rumah dan perbaikan dan petugas tidak melakukan stigma dan diskriminasi terhadap mereka. Mereka berharap petugas lebih ramah, lebih care serta lebih menjaga cara bicara dan sikap.

\section{PEMBAHASAN \\ Pernah mendapat stigma dan diskriminasi dari petugas kesehatan}

Stigma terkait HIVIAIDS muncul dari persepsi tentang penyimpangan perilaku ODHA dari normanorma sosial di masyarakat. ODHA dilabeli "tidak bermoral," "kacau", dan "sesat" (Addo \& Lundmark, 2015). Masyarakat beranggapan bahwa ODHA berbeda dari mereka. Pembedaan ini karena masyarakat memiliki ketakutan, prasangka atau sikap negatif terkait HIV. Stigma terkait HIV menyebabkan ODHA tidak diperlakukan dengan hormat dan bermartabat. ODHA dihina, ditolak, digosipkan dan dikeluarkan dari kegiatan sosial. Ekstremnya, stigma dapat mendorong orang melakukan kekerasan fisik pada ODHA (Pebody, 2018).

Tingginya stigma dan diskriminasi masih menjadi salah satu hambatan terbesar dalam pencegahan dan penanggulangan HIVIAIDS di Indonesia (Shaluhiyah, Musthofa, \& Widjanarko, 2014). Bukan hanya masyakarat awam, petugas kesehatan juga melakukan stigma dan diskriminasi terhadap ODHA (Maharani, 2014). Penelitian di Puskesmas Tanah Pasir Aceh Utara menemukan bahwa masih banyak tenaga kesehatan yang memiliki tingkat stigma dan diskriminasi yang tinggi terhadap ODHA (Sofia, 2016).

Penelitian ini mendapatkan bahwa stigma dan diskriminasi yang dilakukan oleh petugas kesehatan terhadap ODHA seperti pelecehan secara verbal, diperlakukan secara negative dan diasingkan. Pelecehan secara verbal yang diterima ODHA oleh petugas kesehatan seperti dilecehkan, dikira sampah, dan dijelek-jelekkan. Penelitian yang dilakuan di Pekanbaru mendapatkan bahwa ODHA mendapat pelecehan secara lisan oleh petugas kesehatan dengan menyebutkan penyakit HIV dengan nada yang lantang. Selain dilecehkan secara lisan, peneliti juga menemukan bahwa petugas kesehatan masih beranggapan bahwa ODHA adalah orang yang tidak benar dan di anggap "jahat" akibat perilaku mereka sendiri (Maharani, 2014).

Hasil studi kasus yang dilakukan di Jakarta pada pengguna narkoba suntik yang terinfeksi HIV bahwa stigma yang mereka terima berupa katakata dan tindakan yang merendahkan, perlakuan kasar, disamakan dengan pasien gangguan mental, dan pendapat yang tidak dipercaya (Ardani \& Handayani, 2017). ODHA mendapat perlakuan negatif akibat dari ketakutan tertular, dimana

Eva Kartika Hasibuan ${ }^{{ }^{*}}$, Novita Aryani ${ }^{2}$, Galvani Volta Simanjuntak ${ }^{3}$

Program Studi Ners, Universitas Sari Mutiara Indonesia. *Email: evakartikahsb86@gmail.com 
petugas kesehatan merasa tidak nyaman pada saat kontak langsung dengan ODHA maupun dengan benda-benda yang digunakan oleh ODHA (Ardani \& Handayani, 2017). Tanpa disadari apa yang mereka perbuat berdampak secara psikologis tidak hanya terhadap pasien ODHA, tetapi juga terhadap lingkungan sekitar termasuk para petugas kesehatan sendiri. Hal tersebut menyebabkan orang tidak mau atau terlambat mengakses layanan terkait HIV karena takut stigma dan diskriminasi tersebut akan menimpa dirinya (Australia Aid, 2015)

Stigma berasal dari dalam dan luar diri ODHA. Stigma dari dalam timbul akibat rasa ketakutan dalam diri ODHA dan juga hasil dari internalisasi stigma dari luar. Stigma dari luar diterima ODHA dalam bentuk diskriminasi, intimidasi dan pembiaran (Ardani \& Handayani, 2017). ODHA yang merasa terstigma akan mengurangi kemungkinan untuk mencari bantuan, menunda pengobatan atau memilih mengakhiri pengobatan yang pada akhirnya akan berdampak pada program pencegahan dan penanggulangan HIVIAIDS serta menurunkan kualitas hidup ODHA (Ardani \& Handayani, 2017; Maharani, 2014; Shaluhiyah et al., 2014).

\section{Mengalami dampak secara psikologi}

Stigma dan diskriminasi memiliki dampak buruk pada kehidupan sehari-hari ODHA (Dahlui, Azahar, Bulgiba, Zaki, Oche, Adekunjo, \& Chinna, 2015). ODHA mengalami depresi dan kecemasan, rasa sedih, rasa bersalah, dan perasaan kurang bernilai. Bahkan stigma \& diskriminasi oleh petugas kesehatan berdampak pada akses dan penggunaan layanan kesehatan serta kepatuhan terhadap antiretroviral (ARV) sehingga dapat menurunkan kualitas hidup ODHA (Ardani \& Handayani, 2017).

Mendapat perlakuan demikan membuat ODHA mengalami ketakutan dalam diri mereka. Perasaan takut terhadap kondisi diri sendiri dan takut terhadap penerimaan masyarakat, serta internalisasi stigma masyarakat atau mengganggap bahwa cap negatif masyarakat terhadap mereka adalah benar. Ketakutan menimbulkan resistansi terhadap tes HIV, rasa malu untuk memulai pengobatan, dan dalam beberapa hal, keengganan untuk menerima pendidikan tentang HIV (Ardani \& Handayani, 2017).

\section{Tetap melanjutkan pengobatan ke layanan kesehatan}

Sampai saat ini obat untuk membunuh HIV belum ditemukan, namun HIV dapat dikendalikan jika pengidap HIV mendapatkan perawatan. Perawatan yang dimaksud salah satunya adalah mengonsumsi Antiretroviral (ARV), yaitu obat yang dapat menghentikan reproduksi HIV di dalam tubuh. Bila pengobatan tersebut bekerja secara efektif, maka kerusakan kekebalan tubuh dapat ditunda bertahun-tahun dan dalam rentang waktu yang cukup lama sehingga orang yang terinfeksi HIV dapat mencegah AIDS. Untuk mendapatkan manfaat ARV, pengidap HIV harus mengonsumsi obat seumur hidup. Sebab, jika tidak, pertumbuhan virus di tubuh tidak terkontrol dan bisa juga muncul resistensi terhadap obat.

Saat ini, ARV disediakan secara gratis oleh pemerintah yang dapat diambil di layanan kesehatan seperti puskesmas dan rumah sakit. Namun, adanya stigma dan diskriminasi oleh tenaga kesehatan menjadi masalah tersendiri bagi ODHA. Stigma dan diskriminasi menjadi penghalang bagi ODHA untuk mengakses pelayanan kesehatan yang optimal. Stigma dan diskriminasi menyebabkan ODHA enggan untuk berkonsultasi, menolak mendapatkan pelayanan kesehatan serta takut untuk membuka status (Nurhayati, Sunjaya, \& Irvan, 2012).

Monitoring Community Indonesia AIDS Coalition (IAC) mengatakan bahwa jumlah ODHA yang ditemukan dan menjalani pengobatan masih rendah. Salah satu penyebabnya adalah stigma dan diskriminasi masih tinggi di masyarakat lantaran penyakit ini dianggap berkaitan dengan penyimpangan moral. Ironisnya, stigma justru lebih tinggi dilakukan tenaga kesehatan di pelayanan kesehatan. Padahal stigma dan diskriminasi hanya akan menjauhkan mereka dari layanan kesehatan, dan justru menyebabkan penyakit ini tidak pernah terkendali (Manafe, 2019).

Hasil penelitian mendapatkan bahwa meskipun menerima stigma dan diskriminasi dari petugas kesehatan, ODHA tetap melanjutkan pengobatan ke layanan kesehatan. Di awal, stigma dan diskriminasi petugas kesehatan menyebabkan ODHA tidak mau atau terlambat mengakses layanan terkait HIV, seiring dengan penerimaan diri dan penyesuaian yang dilakukan, mereka kembali melanjutkan pengobatan. Cepat lambatnya

Eva Kartika Hasibuan ${ }^{1^{*}}$, Novita Aryani ${ }^{2}$, Galvani Volta Simanjuntak ${ }^{3}$

Program Studi Ners, Universitas Sari Mutiara Indonesia. *Email: evakartikahsb86@gmail.com 
penerimaan dan penyesuaian diri ODHA terkait dengan koping diri ODHA.

Koping merupakan proses kognitif dan tingkah laku yang digunakan oleh seseorang untuk mempertahankan rasa kendali terhadap situasi, mengurangi rasa tidak aman, dan menghadapi situasi yang menimbulkan stress (Arriza, Dewi, \& Kaloeti, 2011). Stress yang dialami ODHA akibat stigma dan diskriminasi, membuat ODHA sering merasa hidupnya tidak berguna lagi, merasa gagal dalam hidup dan berakibat ke mekanisme koping yang negatif. Koping yang efektif atau mekanisme koping yang positif menempati tempat yang sentral terhadap ketahanan tubuh dan daya penolakan tubuh terhadap gangguan maupun serangan suatu penyakit baik bersifat fisik maupun psikis dan social (Arriza et al., 2011). Penelitian ini mendapatkan bahwa ODHA memiliki koping yang positif. Meskipun mendapat stigma dan diskriminasi dari petugas, mereka tetap melanjutkan pengobatan. ODHA bersikap menerima dan tidak meresponi stigma dan diskriminasi yang diterimanya karena mereka menganggap bahwa mereka butuh ARV dan butuh petugas kesehatan untuk pengobatan penyakitnya. Namun, ada juga ODHA yang pindah layanan kesehatan untuk tepat mendapatkan pengobatan. Pemilihan dan pengembagan strategi coping akan sangat menentukan perjalanan ODHA dalam menghadapi penyakitnya (Hidayanti, 2013). Koping efektif yang dimiliki oleh ODHA mungkin dikarenakan pendampingan ODHA berjalan dengan baik sehingga kesadaran untuk mengonsumsi ARV secara teratur makin besar.

\section{Harapan ODHA terhadap layanan kesehatan}

Awal terinfeksi HIV, banyak dari ODHA berpikir hidup mereka tidak lama lagi, hanya menunggu kapan dipanggil oleh Yang Maha Kuasa. Stigma dan diskriminasi di pelayanan kesehatan membuat ODHA enggan melakukan pengobatan makin membuat ODHA merasa sudah tidak ada lagi harapan bagi mereka. Namun, seiring berjalannya waktu, pemahaman ODHA tentang HIVIAIDS semakin meningkat, memunculkan harapan di dalam diri ODHA. Harapan itu memberi ODHA semangat dalan menjalani hari dan tahu apa yang mau mereka tuju serta harapan memberikan ODHA kekuatan ekstra melewati tantangan yang ada.

Harapan muncul setelah ohda memiliki mekanisme koping positif. Mekanisme koping posotif membuat ODHA cepat menerima diri mereka. Penerimaan diri yang baik membuat ODHA memiliki harapan-harapan terhadap masalah yang dihadapi mereka. Harapan ODHA terhadap diri mereka adalah ingin mencapai level undetected. ODHA juga berharap obat HIV seera ditemukan. Harapan ODHA pada layanan kesehatan adalah meningkatkan mutu layanan. Layanan yang dimaksud berdasarkan hasil penelitian adalah petugas kesehatan melakukan penyuluhan secara berkala, melakukan kunjungan rumah, dan perbaikan pendokumentasian rekam medik ODHA. selain itu, harapan ODHA terhadap petugas kesehatan adalah tidak melakukan stigma dan diskriminasi. ODHA berharap petugas kesehatan lebih ramah, lebih care, serta menjaga ucapan dan sikap sehingga ODHA tidak takut lagi untuk mengakses pelayanan kesehatan. ODHA akan merasa nyaman menjalani pengobatannya. Hal ini akan mendukung program pencegahan dan pengobatan HIVIAIDS.

\section{SIMPULAN}

ODHA mengalami stigma dan diskriminasi di pelayanan kesehatan. Stigma yang didapatkan ODHA seperti menerima pelecehan secara verbal, mendapatkan perlakuan negative dan menerima pengasingan diri. Stigma dan diskriminasi di pelayanan kesehatan berdampak pada psikologi ODHA. ODHA mengalami perubahan mental seperti ketakutan, gampang tersinggung, dan "down". Meskipun ODHA menerima stigma dan diskriminasi tersebut, ODHA memiliki koping yang positif shingga ODHA tetap melanjutkan pengobatan di pelayanan kesehatan. Koping yang dilakukan ODHA seperti tidak mengambil hati, pindah layanan kesehatan, dan menerima.ODHA memiliki harapan bisa sembuh, obat ODHA ditemukan dan obat HIV tetap gratis dan disubsidi pemerintah, layanan kesehatan ditingkatkan dan petugas lebih care dan ramah serta menjaga ucapan dan sikap terhadap ODHA.

\section{SARAN}

Diharapkan kepada ODHA tetap mempertahankan koping yang positif dalam menghadapi stigma dan diskriminasi di pelayanan kesehatan. bagi petugas kesehatan diharapkan tidak melakukan stigma dan diskriminasi bagi ODHA mengingat hal tersebut berdampak pada program pengobatan dan pencegahan HIVIAIDS.

Eva Kartika Hasibuan ${ }^{1^{*}}$, Novita Aryani ${ }^{2}$, Galvani Volta Simanjuntak ${ }^{3}$

Program Studi Ners, Universitas Sari Mutiara Indonesia. *Email: evakartikahsb86@gmail.com 


\section{DAFTAR PUSTAKA}

Addo-Atuah, J., \& Lundmark, W. (2015). Book Review: Stigma, Discrimination, and Living with HIVIAIDS: A Cross-Cultural Perspective. Frontiers in Public Health, 3, 242. doi:10.3389/fpubh.2015.00242 Pebodi, R.(2018). What is stigma?. Diakses pada 10 Agustus 2019 Retrieved from https://www.aidsmap.com/abouthiv/what-stigma

Ardani, I., \& Handayani, S. (2017). Stigma terhadap Orang dengan HIV / AIDS ( ODHA) sebagai Hambatan Pencarian Pengobatan: Studi Kasus pada Pecandu Narkoba Suntik di Jakart. Buletin Penelitian Kesehatan, 45(2), 81-88. https://doi.org/10.22435/bpk.v45i2.6042.81-88

Arriza, B. K., Dewi, E. K., \& Kaloeti, D. V. S. (2011). Memahami rekonstruksi kebahagiaan pada orang dengan HIVIAIDS (ODHA). Jurnal Psikologi Undip, 10,(2), 10(2), 153-162.

Australia Aid. (2015) Kajian Dokumen Kebijakan HIVAIDS dan Sistem Kesehatan di Indonesia. Laporan Penelitian. Yogyakarta : PKMK FK UGM. Retrieved from https://www.kebijakanaidsindonesia.net/id/artikel/ artikel-tematik/1473-

Carsita, W. N., Winarni, I., \& Lestari, R. (2016). Studi Fenomenologi: Orang Dengan Hiv Aids (Odha) Dalam Menjalani Self-Disclosure Di Wilayah Kerja Puskesmas Bongas. Jurnal IImu Keperawatan, 4(2), 205-224.

Dahlui, M., Azahar, N., Bulgiba, A., Zaki, R., Oche, O. M., Adekunjo, F. O., \& Chinna, K. (2015). HIVIAIDS Related Stigma and Discrimination against PLWHA in Nigerian Population. PloS one, 10(12), e0143749. doi:10.1371/journal.pone.0143749

Hidayanti, E. (2013). Strategi Coping Stress Perempuan Dengan Hiv / Aids. Sawwa Jurnal Studi Gender, 9(1), 89-106.

Indriani, S. D., \& Fauziah, N. (2017). Karena Hidup Harus Terus Berjalan (Sebuah Studi Fenomenologi Kehidupan Orang dengan HIVIAIDS). Empati, 6(1), 385-395.
Kharimaturrohmah, I., \& Shaluhiyah, Z. (2013). Pengaruh Sikap Teman dan Orangtua terhadap Stigma ODHA oleh Mahasiswa Keperawatan STIKes Kota Yogyakarta. Jurnal Promosi Kesehatan Indonesia, 8(2), 131-140.

Maharani, R. (2014). Stigma dan Diskriminasi Orang Dengan HIV / AIDS ( ODHA ) pada Pelayanan Kesehatan di Kota Pekanbaru Tahun 2014. Jurnal Kesehatan Komunitas, 2(5), 225-232.

Manafe, D. (2019). Dapat Stigma Negatif dari Petugas , 220 . 000 ODHA Enggan Jalani Pengobatan. Retrieved from Berita satu website: https://www.beritasatu.com/kesehatan/565207/da pat-stigma-negatif-dari-petugas-220000-odhaenggan-jalani-pengobatan

Nurhayati, E., Sunjaya, D. K., \& Irvan, A. (2012). Stigma dan Diskriminasi Terhadap ODHA di Kota Bandung. Universitas Padjadjaran. Jurnal Keperawatan, 5(1), 1-10.

Shaluhiyah, Z., Musthofa, S. B., \& Widjanarko, B. (2014). Stigma Masyarakat terhadap Orang dengan HIV / AIDS (Public Stigma to People Living with HIVIAIDS). Jurnal Kesehatan Masyarakat Nasional, 9(4), 333-339. https://doi.org/10.21109/kesmas.v9i4.740

Sofia, R. (2016). Stigma Dan Diskriminasi Terhadap ODHA (Studi Pada Tenaga Kesehatan Di Puskesmas Tanah Pasir Aceh Utara). Jurnal Kedokteran Dan Kesehatan Malikussaleh, 2(1), 79-89. https://doi.org/10.29103/av.v2i1.423

The Joint United Nations Programme on HIV and AIDS (2018). UNAIDS data 2018. di akses 10 Agustus 2019 Retrieved from https://www.unaids.org/sites/default/files/media.../ unaids-data-2018_en.pdf\%0A

Utami, S. (2018). HIV/AIDS Dalam Sustainable Development Goals (SDGs): Insiden, Permasalahan, Dan Upaya Ketercapaian Di Indonesia.

Waluyo, A., Nova, P. A., \& Edison, C. (2011). Perilaku Perawat Terhadap Orang Dengan HIVIAIDS Di Rumah Sakit Dan Puskesmas. Jurnal Keperawatan Indonesia, 14(2), 127-132.

Eva Kartika Hasibuan ${ }^{1^{*}}$, Novita Aryani ${ }^{2}$, Galvani Volta Simanjuntak ${ }^{3}$

Program Studi Ners, Universitas Sari Mutiara Indonesia. *Email: evakartikahsb86@gmail.com 